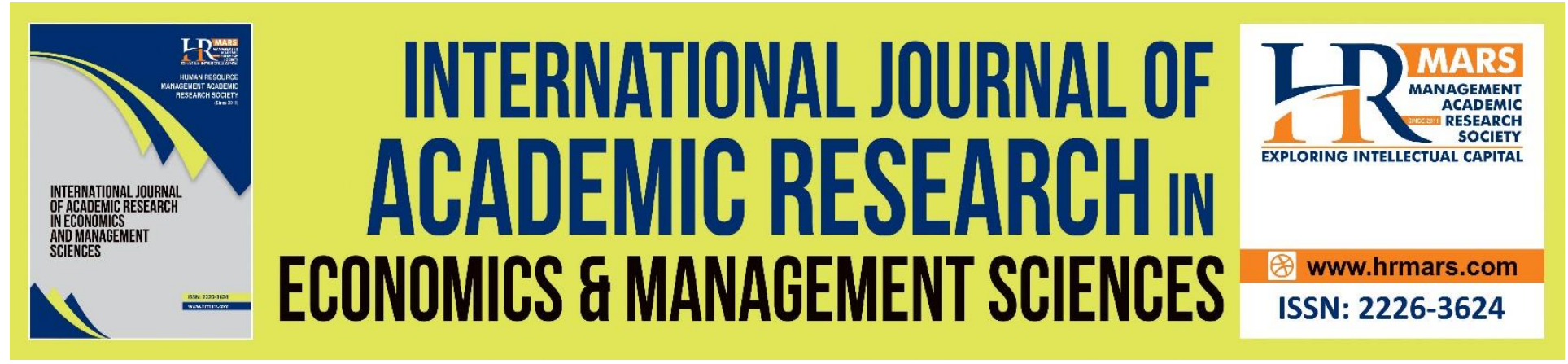

\title{
Capability of Financial Variables to Raise the Productivity of Investment: A Reassessment for the Mexican Economy
}

Garcia Paez Benjamin

To Link this Article: http://dx.doi.org/10.6007/IJAREMS/v10-i2/10069

DOI:10.6007/IJAREMS/v10-i2/10069

Received: 20 April 2021, Revised: 22 May 2021, Accepted: 08 June 2021

Published Online: 29 June 2021

In-Text Citation: (Benjamin, 2021)

To Cite this Article: Benjamin, G. P. (2021). Capability of Financial Variables to Raise the Productivity of Investment: A Reassessment for the Mexican Economy. International Journal of Academic Research in Economics and Managment and Sciences, 10(2), 110-124.

Copyright: (C) 2021 The Author(s)

Published by Human Resource Management Academic Research Society (www.hrmars.com)

This article is published under the Creative Commons Attribution (CC BY 4.0) license. Anyone may reproduce, distribute, translate and create derivative works of this article (for both commercial and non-commercial purposes), subject to full attribution to the original publication and authors. The full terms of this license may be seen

at: http://creativecommons.org/licences/by/4.0/legalcode

Vol. 10, No. 2, 2021, Pg. 110 - 124

http://hrmars.com/index.php/pages/detail/IJAREMS

JOURNAL HOMEPAGE

Full Terms \& Conditions of access and use can be found at http://hrmars.com/index.php/pages/detail/publication-ethics 


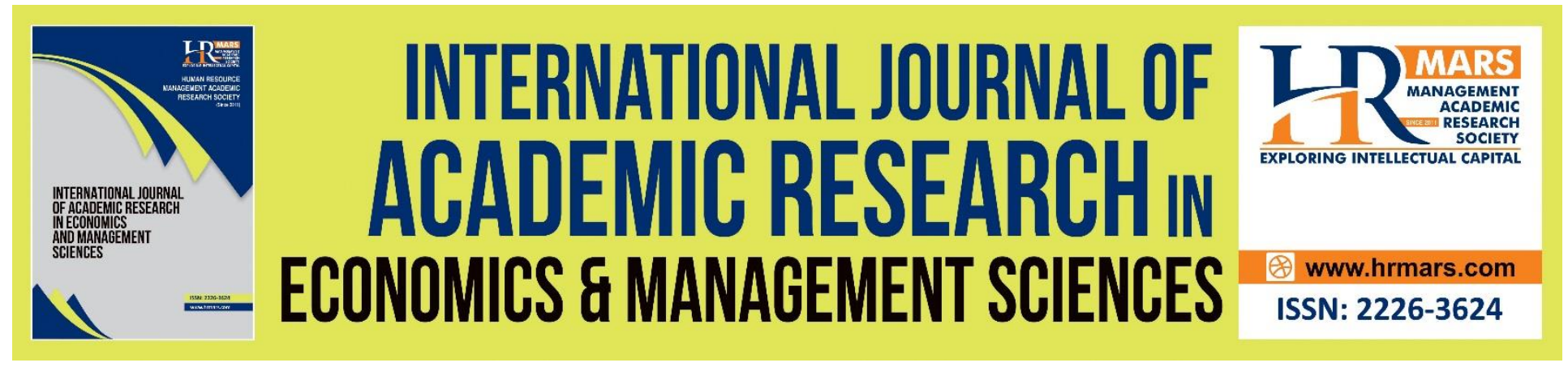

\title{
Capability of Financial Variables to Raise the Productivity of Investment: A Reassessment for the Mexican Economy
}

\author{
Garcia Paez Benjamin \\ Professor of Economics at the National University of Mexico (UNAM). Facultad de economía, \\ Primer piso, Circuito Escolar, Ciudad Universitaria, UNAM, 04310 Coyoacán, CDMX, México. \\ Email: garpaez@unam.mx
}

\begin{abstract}
Departing from the prior-saving approach, which predicts financial development encourages economic growth by raising the amount of lendable funds, this paper analyses the effect of financial variables -real rate of interest and financial deepening ratio, on the productivity of investment. However, testing the performance of the Mexican economy over the 1970-2020 period, evidence lays on the investment-led approach favour, i.e., that as the economy grows it generates additional and new demand of resources from the financial system. Nothing to do with the pretended greater quality of private investment over public investment. To document such finding, firstly, the research describes the sort of financial cul-de-sac Mexico seems to endure in the 1980's as a huge external debt combined with growing external interest rates lured into the overhaul of its financial system. Secondly, both the liberalisation and the post-Keynesian financial models are depicted on their relevant basics. It also assigns a special emphasis to the financialdeepening ratio. Thirdly, the effect of financial variables on the productivity of investment are tested. Finally, conclusions to be drawn from this research are drawn, standing out that it cannot be concluded financial variables determine the productivity of investment.

Keywords: Financial-Liberalisation, Financial-Deepening Ratio, Incremental Capital-Output Ratio, Investment Productivity, and Neoclassical-Post-Keynesian Financial Models.

\section{Introduction}

Based on the original models of Mackinnon y Saw (1973) and the effects of an economic malaise unleashed by low and even negative rates of growth of GDP, a sharp drop in the levels of savings, and investment, of real per capita income real, let alone let alone the morphing external financial conditions just in the mid of a huge external debt, in the 1980s Mexico undertook a financial liberalisation process whose standpoint was the need to increase the internal sources of finance. As in the rest of the economy, the financial sector was affected by the liberalisation process as part of the gradual shift in the overall strategy on economic policy from being state-directed
\end{abstract}


towards a market forces-led economy under which the participation of the private sector in economic is enhanced. Hence, the larger the reliance of the Mexican economy between financial variables and the private sector, the larger the need for a modern financial sector.

In 1988, the sector liberalisation programme was facilitated due to earlier phases of institutional and administrative reforms. Firstly, in the mid-1970s the institutional structure of the financial system was modernised and, additionally, the government initiated the creation of a Treasury Bill (CETES) market. ${ }^{1}$ Secondly, after the 1982 devaluation and the subsequent weakening of the financial position of private sector commercial bank, the outgoing administration nationalised the Mexican banking system. Although, with the aim of reviving private sector confidence in the government, the new administration starting in 1983 negotiated the resale of one third of the banks' assets and invited the then dispossessed members of the private banking sector to manage the brokerage houses, which opera ted in an unregulated financial framework, i.e., they were not subject to compulsory reserve requirements.

The relative success enjoyed by the private brokerage houses in comparison to the poor performance of government-owned banks was an early justification for a comprehensive liberalisation of the banking sector, in April 1989. The government's liberalisation policies resulted in the eventual re-privatisation of the commercial banks, which were the larger financial intermediaries and the main providers of credit to the private sector. The crowning event to consolidate the liberalisation process, however, took place when in 1994 the Bank of Mexico became a constitutional autonomic entity. ${ }^{2}$

- The objective is to analyse the effect of financial variables- the real interest rate and the financial deepening ratio, on the productivity of investment such as it was argued for the financial liberalization advocates.

So, subscribing that the thorough financial sector liberalisation process undergone by Mexico did not neither increased nor diversified the internal sources of savings, this paper attempts to discern that hypothesis by analysing the interrelationship between financial variables and real economic variables on the quality of investment as measured by the Incremental Capital ratio (ICOR), over the 1970-2019 period, which is long enough to contrast 1970-1990 and 1990-2020 subperiods and thus to compare the ability of the financial variables to stimulate productivity of investment before and after the above-referred milestone changes in the financial sector of Mexico.

1 As the CETES value was decided in an auction after the government announced the amount to be issued, their rate of return was a more flexible than the interest rate offered on bank deposits. In fact, it was used by the monetary authorities to fix the interest rate ceilings at that time.

2 "The state will have a central bank which will be autonomous in execution of its functions and management, so that it won't be any longer an office of the federal public administration", the $28^{\text {th }}$ article of the Constitution of Mexico quoted. 


\section{The Theory of Financial Liberalisation}

The hypothesis stating that positive real interest rate increases the average productivity of investment is probably the strongest theoretical argument supporting the liberalisation of the financial system, given the theoretical and empirical weakness of the positive relationship between real interest rate and financial deepening on the one hand, and aggregate savings on the other.

The effect of interest rate on the efficiency of investment is more effective than its effect on the amount of savings (and investment) since the latter depends on the result of the substitution and income effects. The true effects of the real interest rates, Fry (1982) argues, is "on the average efficiency of investment, not its volume" (p.737). Mackinnon (1989) points out that "apparently the quality, if not the quantity of investment improves significantly, when interest rates are positive and financial intermediation is robust" (p.34). Quoting Collier and Mayer (1989): "As both Fry and Mackinnon note, if the gains from savings are modest, the substantial gains hypothesized for domestic financial liberalisation stand or fall by improvements in investment allocation" (p.7).

On the empirical analysis of the effectiveness of the real interest rate and the financial deepening ratio as determinants of the productivity of investment, Fry (1979 and 1989) tests the effect of the real interest rate on the Incremental Capital-Output Ratio (ICOR) for the case of Turkey over the period 1950-1977. He does so by regressing the ICOR on the real interest rate measured as the difference between the deposit interest rate and expected inflation. He argues that "if average investment efficiency is monotonically related to the Incremental Output-Capital Ratio (IOCR) ( $\sigma)$, a positive association between the IOCR and dis-equilibrium real deposit rates would support the efficiency analysis [where the real interest rate affects investment efficiency by discouraging those investment projects whose real rate of return is lower than the real interest rate offered on deposits] (Fry, 1989, p.147). The estimation results obtained by Fry (1979) are:

$$
\begin{gathered}
\frac{\Delta K}{\Delta Y}=v=2.53-24.87(d-i) \\
\quad(5.84)(-3.0) \\
R^{2}=0.253 D W=1.93
\end{gathered}
$$

...where $v$ is the ICOR, $d$ is the nominal deposit rate, and $i$ is the inflation. Based on these results, Fry concludes for the case of Turkey over the years 1950-1977 that a chance in the real deposit rate positively affects the productivity of investment: a one percentage point increase in the real interest rate raises the IOCR by 0.249 .

Polak (1989) stress the importance of market determined equilibrium real interest rates on the determination of the level and quality of investment. No government intervention in financial markets is the only way, he argues, in which a country can devote the resources at its disposal to the best investment projects. ${ }^{3}$ By these means, he continues, the country can block off projects with low or negative marginal productivity, because projects that could not pay the market costs of capital ${ }^{4}$, would be screened out of the market. "Self-investment projects that promised less the prevailing market yield would not be undertaken, since the saver would have the alternative

${ }^{3}$ Where best means the investment projects with the highest marginal contribution to output.

${ }^{4}$ This is to say, the real loan interest rate. 
opportunity of earning the market yield by using any one of the available channels for intermediation "(Polak, 1989, p.56).

Polak argued that in less developed countries, artificially set low real interest rates lead to the fragmentation of the capital market and to the inefficient allocation of savings into low yield investment projects. Setting real interest rates at an artificial low level makes "room in the queue of savings for projects that would automatically be disqualified on the basis of an equilibrium rate of interest, controls on real interest rates cause the use of part of the available scarce savings for the execution of sub-optimal investment projects and the concomitant exclusion of a larger amount of more deserving projects" (Polak, 1989, p.60). The level of real interest rates, he argues, is an indicator of the fragmentation of the capital market, and at the same time, one of the causes of it. The greater the distance between an equilibrium market clearing rate and the actual level at which controlled interest rates are set, the stronger the forces toward a distorted capital market.

To support empirically the argument that artificially set real interest rates and distorted capital markets hamper the rate of growth of output, Polak reports the result of work done by the World Bank, where, for a sample of 40 developing countries, from 1960 to 1980, an increase in the real interest rate $(\mathrm{RRI})$ is associated with a higher growth rate $(\mathrm{y}):^{5}$

$$
\begin{array}{r}
y=5.21+0.27 R R I \\
(15.3)(4.5) \\
R^{2}=0.3
\end{array}
$$

\section{Financial Deepening}

Shaw's financial deepening hypothesis argues that the financial deepening, or the accumulation of non-financial assets at a pace faster than the accumulation of non-financial wealth, will tend to increase real savings: "Measures to raise real rate of return on financial assets, to reduce the variance of returns, and to improve financial technology, along with allied measures in nonfinancial areas, extend the saver's horizons over both space and time" (Shaw, 1973, p.72). A positive and significant relation between the "size" of the financial system, measured by the ratio of $\mathrm{M}_{4}$ to GDP, and real domestic savings would be expected. However, the interpretation of the financial intermediation ratio's (M4/GDP) coefficient in the level of savings remains ambiguous. Quoting Gupta (1987): "The difficulty with this variable [the financial intermediation ratio] lies in the interpretation of its coefficient. What meaning can be attached to it? Even if the sign of the coefficient could suggest the direction of the effect of financial development on savings, it is not clear whether we could go further and say that if financial assets as a proportion of GNP increase by a certain amount, aggregate savings will increase by a specific amount. Given this ambiguity we use (this ratio) as indicating only a directional effect rather than attaching any meaning to the size of its coefficient" (p.304).

To test the financial deepening hypothesis, the ratio of $\mathrm{M}_{4}$ (the broadest monetary aggregate) to Gross Domestic Product (as a measure of financial deepening) is introduced as an explanatory variable in the total real domestic saving equation:

$$
\begin{aligned}
\operatorname{Ln} D S= & -1.48+0.94 \ln G D P-0.002 r+0.165 \ln \left(\frac{M_{4}}{G D P}\right)-0.79 D U_{86} \\
& (1.34)(1.34) \quad(-1.17)
\end{aligned}
$$

5 T-statistics in brackets. 


$$
R^{2}=0.95 \quad D W=-1.95 \quad F=109.4 \quad n=30
$$

The financial variable $M_{4} / G D P$ is not statistically significant in explaining the level of total domestic Real savings. To eliminate the possibility of autocorrelation between InGDP and $\ln \left(\mathrm{M}_{4} / \mathrm{GDP}\right)$ we dropped InGDP from the equation and let the real level of domestic savings be explained by changes in the real interest rate and the intermediation ratio alone. The result obtained is the following:

$$
\begin{aligned}
& \text { LnDS }=-1.51-0.001 r+1.41 \ln \left(\frac{M_{4}}{G D P}\right)-0.84 D U_{86} \\
& \text { (9.04) (0.61) } \\
& R^{2}=0.9 \\
& D W=2.08 \\
& F=105.6 \quad n=30
\end{aligned}
$$

Although the t-value of the financial intermediation ratio's coefficient rose, it is still not statistically at the $5 \%$ significance level, but it is statistically different from zero at the $10 \%$ level of significance. This result allows us to argue that although a positive relation exists between the financial intermediation ratio and the level of domestic savings, the relationship is weak. It cannot be concluded that financial deepening has an independent effect on the level of real savings.

\section{The Post-Keynesian Perspective}

The post-Keynesian models consider the effects of financial liberalisation under the assumption that investment is not supply determined, but demand determined. It is not savings what determine investment but, on the contrary, investment determines aggregate savings through income multiplier effect or income redistribution. The Keynesian view is opposed to the belief that investment and output growth are constrained by savings.

Under the Keynesian theoretical framework, the level of income of the economy is determined by effective demand. ${ }^{6}$ Savings is determined by the level of income and will be equal to investment. ex-post.

Economic policy is oriented towards the rise of effective demand, as opposed to the neoclassical view that stresses the importance of arising the levels of savings. Moreover, inflation itself can encourage investment by rising the nominal rate of return on investment and by reducing the real rate of interest (Thirlwall, 1989) Since capital assets and financial assets are substitutes and not complementary, a reduction in the real interest rate will encourage investment because of the real return of investment being higher than the real yield of financial assets. The effect of high real interest and of economic policies promoting savings might deter investments, consumption, effective demand, and economic growth.

Burkett and Dutt (1991) develop a model to analyse the effects of an increase in the real deposit rate of interest. Interest rates affect both consumption and investment. As opposed to the liberalisation models, they highlight the relevance of the possible negative effect on consumption, on demand, and hence on economic growth. Consumption (C) is a function of income $(\mathrm{Y})$ and the propensity to save $S_{i d}$ :

$$
C=\left[1-s\left(i_{d}\right)\right] Y
$$

It is assumed that interest rates do affect savings:

${ }^{6}$ Effective demand is the sum of aggregate consumption, investment, and the government's deficit (plus exports minus imports in an open economy). 


$$
s^{\prime}\left(i_{d}\right)>0
$$

Investment is determined by expectations on the yield of capital assets net of prospective borrowing costs.

$$
\begin{array}{cc}
I=I(r, i) & (7) \\
\frac{\delta I}{\delta r}>0 & \frac{\delta I}{\delta i}<0
\end{array}
$$

Where: $r$ is the rate of profits and $i$ is the loan interest rate. Investment decisions are not directly on demand affected by an increase in the supply of loans but by its effects on the loan interest rate. In the credit market, the supply of loans $L^{s}$ is a function of the level of deposits held in the banking system, $D$, the reserve ratio (1-q), and the proportion of free reserves which banks lend to firms $(\alpha)$. The proportion $\alpha$ varies positively with the loan interest rate:

$$
L^{S}=\alpha(i)(q) D
$$

Deposits held in the banking system are a function of wealth and of the real deposit interest rate.

$$
D=b\left(i_{d}\right) W b^{\prime}\left(i_{d}\right)
$$

The model follows the assumption that a higher interest rate will increase the availability of credit. The demand for loans is fixed in the short run by the difference between nominal capital stock $(\mathrm{pK})$ minus the total wealth of firms $(\mathrm{F})$

$$
L d=(p K)-F=\bar{L}(10)
$$

Investment is either self-financed or financed through bank credit. Loan demand is inelastic to the loan interest rate in the short run. Nevertheless, the loan rate can affect investment through expectations.

Equilibrium in the credit market implies:

$$
\begin{aligned}
L^{S} & =L^{d} \quad(11) \\
\alpha(i)(q) D & =p k-F=\overline{\mathrm{L}}
\end{aligned}
$$

The equilibrium interest rate varies positively with the loan demand and the reserve ratio (1-q) and negatively with the proportion of free reserves lent to firms, the deposit of interest rate and wealth. An important result is that an increase on the deposit rate of interest will cause the equilibrium rate to fall (because it increases the supply of loans).

In the good market, output $X$ equals aggregate consumption $C$ plus investment I:

$$
X=C+I
$$

Substituting the consumption and the investment equations, (22) and (24) respectively.

$$
X=\left[1-s\left(i_{d}\right)\right] Y+I(i, r)
$$

Since income $Y$ is either earned by labour ( $w$ ) or by interest od deposits:

$$
X=\left[1-s\left(i_{d}\right)\right]\left(w+i_{d} D\right)+(I(i, r))
$$

Once the equilibrium interest rate is set, equilibrium in the good market is determined by effective demand (the intersection point where aggregate demand meets aggregate supply).

$$
X^{e}=\left[1-s\left(i^{e}\right)\right](w+i D)+I\left(i^{e}+r\right)
$$

Both an income and a substitution effect caused by the rise in the deposit rate of interest on consumption are implicit in this equation. An increase in $i^{e}$ will increase total income $(w+i D)$, causing consumption and output to grow. The substitution effect causes an increase in the propensity to save and decreases consumption. The total effect on consumption will depend on the relative magnitude of these effects.

A rise in the deposit rate increases the supply of loans and causes the loan interest rate to decrease. This causes expectations of net returns on capital to increase hence investment grows. 
The effect on total output depends on the magnitude of these tree different effects. The effect on output can be negative if consumption decreases more than investment increases. In turn, the effect of interest rate movements on consumption depends on the propensity to save, the effect on the investment depends on its sensitivity to the loan interest rate. A lower sensitivity of investment to the loan interest rate increases the likelihood of a negative effect on output. As well if investment is more sensitive to changes in the rate of profit than in the loan rate of interest, then the effect of a rise in $i^{d}$ can be negative on investment.

The relevance of the effect of a rise in the real deposit interest rate on consumption distinguishes the post-Keynesian models from the neo-classical ones. The former explicitly state the possibility of a reduction in effective demand because of a rise in the real deposit interest rate. Nevertheless, the possibility of an increase in the real deposit of interest rate to increase output also exists. This happens because the three assumptions taken in the model; firstly, the assumption that saving and consumption are interest rate elastic allows the possibility of an increase in consumption because of a rise in the real deposit rate (income effect on consumption). Secondly, the supply of loans increases when the real deposit rate increases. And thirdly, the real loan rate decreases when the supply of loans grows.

There are several aspects worthwhile mentioning concerning the post-Keynesian models. Firstly, financial liberalisation can have the same positive results on savings, investment and growth as claimed by the neoclassical models because of the assumptions highlighted above. Secondly, financial liberalisation implies an increase, not a decline, in the real loan interest rate. Interest rate ceiling apply to both deposit and loan rates hence the neo-classical argument stating that productivity increases when the financial sector is liberalised. A decline in the loan rate, as supposed by the post-Keynesian models, abolishes one of the advantages proposed by the pro financial models. Thirdly, Keynesian theory opposes the view that that prior savings is needed for investment. There is no need to increase the funds available for investment via increases in the real interest rate. "Prior saving has no more tendency to release funds available for investment than prior-spending has" (Keynes 1939). Even though credit is needed for investment, credit is not determined by savings: "credit expansion provides not an alternative to increase savings, but a necessary preparation for it. It is the parent, not the twin, of increased savings" (Keynes 1939". An increase in savings will probably be needed in the long run to finance investment, "the provision of long-term finance at reasonable terms and thus the achievement of higher investment, may, in certain circumstances, be contingent on the expectation of a substantial increase in the flow of savings into the security market" (Asimakopoulos,1986, p.88). Credit from the banking system will generate the flow of savings through the growth of investment an income. These savings will be needed to finance long-run investment.

\section{The Methodology}

Financial liberalization theory predicts a negative relationship between the real interest rate and the ICOR: the higher the real interest rate, the higher the expected rate of return of investment projects, which assumes a higher level of productivity. Concerning self-financed investment, entrepreneurs will not invest if the expected yield of the project is lower than the real deposit interest rate offered in financial markets, thus forcing the investment projects to be 117ehavior to have a high expect rate of return, and hence, it is assumed, a high level of productivity. Concerning investment projects financed by the banking system, lenders will not be willing to 
finance projects the expected yield of which is not enough to cover payments. This process forces those investment projects to be financed by banks, to have an expected rate of return and productivity.

It is also argued that financial depth contributes to growth by improving the productivity of investment. Provided that intermediaries are good at selecting viable projects, greater intermediation will ensure that the better investment projects are financed and will therefore increase average productivity (see World Bank, 1989). The larger the number of resources 118 ehavior118 to the financial system, the larger the amount of investable funds can be efficiently allocated.

In addition to financial variables, we include the rate of growth of output $\dot{g}$ as an explanatory variable to test the hypothesis of $\dot{g}$ having a negative effect on the ICOR (a positive effect on the productivity of investment). According to Leibenstein (1966) the ICOR in the short run is determined by $\dot{g}$ and the degree of 118ehavior118on (see Thirlwall, 1989). If the economy is coming out of a recession, a rise in $\dot{\mathrm{g}}$, (which implies $\Delta \mathrm{Y}_{\mathrm{t}}>\Delta \mathrm{Y}_{\mathrm{t}-1}$ ) will take place with low investment $(\Delta \mathrm{K})$ since there is spare capacity, ante ICOR, $\Delta \mathrm{K} / \Delta \mathrm{Y}$, will have a relatively low value. On the other hand, when the rate of growth of output is decreasing, $\Delta \mathrm{Y}_{\mathrm{t}}<\Delta \mathrm{Y}_{\mathrm{t}-1}$, and investment remains stable, the ICOR increases, Hence, a negative relationship is expected between the rate of growth of output and the ICOR.

Furthermore, It is assumed that investment $\Delta \mathrm{K}$ varies less than output $\Delta \mathrm{Y}$, that is, investment is considered to have a more stable 118ehavior than output. According to Leibenstein, the investment rate is more stable than growth for the following reasons: firstly, government investment is likely to change slowly. Public investment has an autonomous behaviour independent of the rate of growth of output, "a zero-growth rate will not reduce government investment to zero" (Leibenstein,1966, p.21). Secondly, private investment may take place for defensive purposes as well as for expansion. Firms invest to defend their relative position with other firms even if the absolute position of the industry does not improve.

\section{Estimation Results}

To test the hypothesis, we specify the ICOR as a function of the real interest rate, the financial deepening ratio (calculated as a ratio of nominal $\mathrm{M}_{4}$ over nominal GDP) and the rate of growth of output, $\dot{\mathrm{g}}$ :

$$
I C O R=f\left(r, \frac{M_{4}}{G D P}, \dot{g}\right)
$$

Dummy variables for the years with a negative rate of growth of output $(1982,1983$, and 1986 for the first subperiod and 1995, 2001, 2002, and 2009, for the second subperiod) are included in the equation. If $\dot{g}$ is negative and $\Delta Y<0$, then ICOR $<0$. But a negative rate of growth of output does not imply necessarily that investment has had a negative productivity. A negative rate of $\dot{g}$ can be due to factor other than the productivity of investment. Thus, including the ICOR values when $\dot{g}$ is negative, may bias the estimated results.

The results obtained for the case of Mexico over the bifurcated 1970-2019 period, are as follows:

The 1970-1990 Sub-Period

$$
I C O R=9.6+0.03 r-0.03\left(\frac{M_{4}}{G D P}\right)-0.74 \dot{g}-47.1 D U_{82}-15.3 D U_{83}-15.5 D U_{86}
$$




$$
\begin{array}{llll}
(3.87)(0.91) & (-0.41) & (-6.09) & (-27.5) \quad(8.53)(-9.78) \\
R^{2}=0.99 & D W=1.53 & F_{(6,14)}=241.0 \quad n=21
\end{array}
$$

...where ICOR is the incremental capital-output ratio of total investment, calculated annually (see table 1$), r$ is the real interest rate (\%), (M4/GDP) is the broadest monetary aggregate in nominal terms and GDP is the gross-nominal domestic product, and $\dot{g}$ is the real growth rate of output (\%). The regression specified included dummy variables for 1995, 2001, 2002, and 2009, during which the rate of growth of output was negative. ${ }^{7}$

According to the above results, we find that neither the coefficients of the real interest rate or that of the financial deepening are statistically significant. The rate of growth of output $\mathrm{g}$ has the expected sign and is statistically significant, supporting Leibenstein hypothesis that the ICOR varies inversely with the rate of growth of output. On the other hand, the evidence does not support the hypothesis which predicts a significant effect of financial variables, such as the real interest rate and the financial deepening ratio, on the productivity of investment.

Further, when $\dot{g}$ is excluded from the ICOR equation, the estimated coefficients of the real interest rate $r$ and that of the financial deepening ratio $\left(M_{4} / G D P\right)$ show that the latter has some significant effect on the determination of the productivity of investment:

$$
\begin{gathered}
I C O R=14.15-0.009 r-0.23\left(\frac{M_{\mathbf{4}}}{G D P}-42.1 D U_{\mathbf{8 2}}-7.3 D U_{\mathbf{8 3}}-11.01 D U_{\mathbf{8 6}}\right. \\
(2.13) \quad(-0.20) \quad(-1.75) \quad(-21.4) \quad(4.5) \\
R^{2}=0.98 \quad D W=1.58 F_{(6,13)}=96.2 \quad n=21 \quad \dot{p}=0.86
\end{gathered}
$$

The 1990-2019 Sub-period

$I C O R=47.22-4.19 r-3.33\left(\frac{M_{4}}{G D P}\right)+14.91 \dot{g}+118.72 D_{95}+19.95 D_{01}-4.35 D_{02}+$ 139. $40 D_{09}(20)$

$$
\begin{array}{llll}
(0.44)(-1.27) & (-1.10)(1.53) & (1.34) & (0.23)(-5.25) \quad \\
R^{2}=0.69 & D W=1.14 \quad F_{(7,22)}=7.26 & n=30 \quad \dot{p}=0.86
\end{array}
$$

...where ICOR is the incremental capital-output ratio of total investment, calculated annually (see table 2). The variables the $r$, and the (M4/GDP) stand as in the 1970-1990 sub-period. The regression specified included dummy variables for 1995, 2001, 2002, and 2009, during which the rate of growth of output was negative.

According to the above results, we find that none of the three coefficients are statistically significant. So that, the evidence does not support the hypothesis which predicts a significant effect of financial variables, such as the real interest rate and the financial deepening ratio, on the productivity of investment. It is noteworthy that as the rate of growth of output $\mathrm{g}$ has not the expected sign and is statistically no significant, the Leibenstein hypothesis is not supported. ${ }^{8}$

${ }^{7}$ In Econometrics including dummy variables improves the estimation results. Otherwise, they could be discarded.

8 This result holds even when dummy variables are dropped. 
When $\dot{g}$ is excluded from the ICOR equation, neither of the estimated coefficients of the real interest rate $r$ and that of the financial deepening ratio (M $\left.M_{4} / G D P\right)$ are statistically significant. In this view, there is the evidence enough to hold that they do not have any significant effect whatsoever on the determination of the productivity of investment:

$$
\begin{array}{cccc}
\text { ICOR }=150.02 & -2.66 r-5.25 & \left(\frac{M_{4}}{G D P}\right)-495.06 D U_{02}(21) \\
(1.93) & (0.99) & (0.23) & (-0.69) \\
R^{2}=0.66 & D W=1.28 & F_{(6,23)}=16 .-66 & n=30
\end{array}
$$

\section{Discussion}

With the purpose of improving allocative efficiency of resources, among other objectives, since 1982 the Mexican financial sector was gradually liberalised predicting that both a rise in the real interest rate to its equilibrium level and the financial deepening ratio would improve the productivity of total investment. However, the empirical analysis undertaken in this paper for the 1970-2019 period allow us to conclude that the effect movements in such variables over the ICOR, as a proxy productivity, are weak.

The quality of investment is determined by many economic and non-economic variables. The main interest of this research laid on the role of financial variables on the productivity of investment and no evidence whatsoever was found of financial variables having a significant effect on the ICOR. This result undermines the hypothesis that a rise in the real interest rate and the financial deepening ratio necessarily improve the productivity of investment. On the other hand, it was found that the productivity of investment is a function of the rate of growth of output but only in the $1970-1990$ sub-period. Incidentally, the phase when the financing remained repressed.

Diversification of finance sources for private investment -companies on the value chain where firms belong to, particularly those at the procurement process, shareholders, etcetera, appears to be at the bottom of much of the wanning participation of banking credit in the investment financing mostly during the 1990-2020 sub-period of study.

Notwithstanding, this is no to say that the orientation of all financial policies set into motion after financial liberalisation were innocuous at all. This paper only provides some insights in the scope of a specific hypothesis arguing that a positive interest rates and the rise of its correlate financialintermediation ratio were key factors to ensure a higher quality of investment, which turned out to be empirically weak. It also shows, however, that other accompanying strategy elements such as a renewed participation of the public sector in the country's economic activities, were absent. And this latter finding is a huge failure, as it is shown that a rise in public investment seems to be a better source of improving either the quantity or the quality of aggregate level of investment than financial variables.

\section{References}

Burkett, P., \& Dutt, A. K. (1991). Interest Rate Policies, Effective Demand and Growth in LDCs. International Review of Applied Economics, Vol. 5, No. 2

Collier, P., \& Mayer, C. (1989). The assessment: Financial Liberalisation, Financial Systems, and Economic Growth. United Kingdom: Oxford Review of Economic Policy, Vol. 5, No. 4 
Fry, M. (1982). Models Financially Repressed Developing Economies. United States of America: World Development, Vol. 10, No.9

Gupta, S. P., \& Bajpai, N. (1989). Financial Reform: Role of Liberalisation. India: Economic and Political Weekly, Vol. 24, No. 44-45.

Mackinnon, R. I. (1989). Financial Liberalisation and Economic Development: a Reassessment of Interest-rate Policies in Asia and Latin-America. United Kingdom: Oxford Review for Economic Policy, Vol. 5, No. 4.

Leibenstein, H. (1966). Incremental Capital-Output Ratios and Growth Rates in the Short Run. Review of Economics and Statistics, Vol. 18, No.1

Polak, J. J. (1989). Financial Policies and Development, Development Centre Studies, OECD, Paris: Development Centre Studies.:

Bosch, R. J. (2013). Revisiting Economic Development, Growth, and Institutions: Oxford University Press

Shaw, E. (1973). Financial Deepening in Economic Development, United Kingdom: Oxford University Press.

Thirlwall, A. P. (1989). Growth and Development with Special reference to Developing Economies. United Kingdom: Palgrave Macmillan. 


\section{Data Appendix}

\begin{tabular}{|c|c|c|c|}
\hline \multicolumn{4}{|c|}{ Table 1. Incremental Capital-Output Ratio* } \\
\hline Year & $(\mathrm{I} / \mathrm{Y}) /(\Delta \mathrm{Y} / \mathrm{Y})$ & $\begin{array}{c}(I p b l / Y) /(\Delta Y / Y \\
)\end{array}$ & $(\operatorname{lprv} / \mathrm{Y}) /(\Delta \mathrm{Y} / \mathrm{Y})$ \\
\hline 1970 & 3.08 & 1.02 & 2.07 \\
\hline 1971 & 4.69 & 1.21 & 3.48 \\
\hline 1972 & 2.49 & 0.80 & 1.69 \\
\hline 1973 & 2.66 & 1.04 & 1.62 \\
\hline 1974 & 3.64 & 1.35 & 2.28 \\
\hline 1975 & 4.08 & 1.69 & 2.39 \\
\hline 1976 & 5.15 & 1.96 & 2.39 \\
\hline 1977 & 5.66 & 2.16 & 3.51 \\
\hline 1978 & 2.64 & 1.16 & 1.48 \\
\hline 1979 & 2.63 & 1.12 & 1.52 \\
\hline 1980 & 3.05 & 1.31 & 1.74 \\
\hline 1981 & 3.44 & 1.56 & 1.88 \\
\hline 1982 & -38.68 & -17.11 & -21.57 \\
\hline 1983 & -2.83 & -1.12 & -1.71 \\
\hline 1984 & 4.58 & 1.77 & 2.81 \\
\hline 1985 & 6.31 & 2.24 & 4.07 \\
\hline 1986 & -4.23 & -1.49 & -2.74 \\
\hline 1987 & 8.61 & 2.65 & 5.96 \\
\hline 1988 & 11.04 & 3.05 & 7.99 \\
\hline 1989 & 5.57 & 1.47 & 4.11 \\
\hline 1990 & 4.84 & 1.25 & 3.59 \\
\hline \multicolumn{4}{|c|}{ Period Averages } \\
\hline 1970-1990 & 1.83 & 0.43 & 1.36 \\
\hline $\begin{array}{l}1970- \\
1990 * * \\
\end{array}$ & 4.95 & 1.69 & 3.20 \\
\hline 1970-1981 & 3.90 & 1.49 & 2.36 \\
\hline $\begin{array}{l}1982- \\
1990^{* *}\end{array}$ & 6.82 & 2.07 & 4.75 \\
\hline \multicolumn{4}{|c|}{$\widehat{\mathrm{o}}=I / I C O R$} \\
\hline 1970-1990 & 0.546 & 2.325 & 0.735 \\
\hline $\begin{array}{l}1970- \\
1990 * *\end{array}$ & 0.214 & 0.591 & 3.048 \\
\hline 1970-1981 & 0.277 & 0.735 & 0.423 \\
\hline $\begin{array}{l}1982- \\
1990^{* *}\end{array}$ & 0.146 & 0.483 & 0.120 \\
\hline \multicolumn{4}{|c|}{ Source: World Development Indicators, World Bank } \\
\hline $\begin{array}{l}\text { Notes: } \\
\left({ }^{*}\right) \text { ICORs }=(\mathrm{I} / \mathrm{Y}) / \\
\left({ }^{* *}\right) \text { It excludes } \\
\text { output was neg }\end{array}$ & $\begin{array}{l}\text { (Y) } \\
2,1983 \text { and } 1986 \text {, } \\
\text { e. }\end{array}$ & ing which the rate $\mathrm{o}$ & rowth of \\
\hline
\end{tabular}


INTERNATIONAL JOURNAL OF ACADEMIC RESEARCH ECONOMICS AND MANAGEMENT SCIENCES Vol. 10, No. 2, 2020, E-ISSN: 2226-3624 @ 2020 HRMARS

\begin{tabular}{|c|c|c|c|}
\hline \multicolumn{4}{|c|}{ Table 2. Incremental Capital-Output Ratio* } \\
\hline Year & $(\mathrm{I} / \mathrm{Y}) /(\Delta \mathrm{Y} / \mathrm{Y})$ & $(I p b \mid / Y) /(\Delta Y / Y$ & $(\operatorname{lprv} / \mathrm{Y}) /(\Delta \mathrm{Y} / \mathrm{Y})$ \\
\hline 1990 & 3.47 & 0.83 & 2.64 \\
\hline 1991 & 4.44 & 0.97 & 3.48 \\
\hline 1992 & 5.54 & 1.07 & 4.47 \\
\hline 1993 & 10.74 & 1.57 & 9.17 \\
\hline 1994 & 4.39 & 0.80 & 3.58 \\
\hline 1995 & -2.60 & -0.47 & -2.13 \\
\hline 1996 & 2.72 & 0.35 & 2.37 \\
\hline 1997 & 2.90 & 0.36 & 2.54 \\
\hline 1998 & 4.08 & 0.43 & 3.66 \\
\hline 1999 & 7.67 & 0.87 & 6.80 \\
\hline 2000 & 4.35 & 0.59 & 3.75 \\
\hline 2001 & -49.29 & -7.32 & -41.98 \\
\hline 2002 & -483.62 & -91.47 & -392.15 \\
\hline 2003 & 13.67 & 2.87 & 10.81 \\
\hline 2004 & 5.22 & 1.08 & 4.14 \\
\hline 2005 & 8.97 & 1.95 & 7.03 \\
\hline 2006 & 4.79 & 1.02 & 3.78 \\
\hline 2007 & 9.58 & 2.01 & 7.57 \\
\hline 2008 & 20.26 & 4.89 & 15.37 \\
\hline 2009 & -4.19 & -1.13 & -3.06 \\
\hline 2010 & 4.22 & 1.10 & 3.12 \\
\hline 2011 & 6.08 & 1.40 & 4.68 \\
\hline 2012 & 6.27 & 1.26 & 5.02 \\
\hline 2013 & 15.69 & 3.26 & 12.44 \\
\hline 2014 & 7.37 & 1.45 & 5.92 \\
\hline 2015 & 6.81 & 1.10 & 5.71 \\
\hline 2016 & 8.67 & 1.35 & 7.32 \\
\hline 2017 & 10.45 & 1.46 & 9.00 \\
\hline 2018 & 10.04 & 1.38 & 8.66 \\
\hline 2019 & -379.02 & -47.82 & -331.20 \\
\hline \multicolumn{4}{|c|}{ Period Averages } \\
\hline $1990-2019$ & -24.34 & -3.76 & -617.50 \\
\hline $\begin{array}{l}1990- \\
2019 * *\end{array}$ & 3.42 & 8.847 & 7.436 \\
\hline $1990-2000$ & 4.336 & 0.695 & 2.756 \\
\hline $\begin{array}{l}2001- \\
2019^{* *}\end{array}$ & 7.536 & 1.837 & 7.369 \\
\hline & & I/ICOR & \\
\hline
\end{tabular}


INTERNATIONAL JOURNAL OF ACADEMIC RESEARCH ECONOMICS AND MANAGEMENT SCIENCES Vol. 10, No. 2, 2020, E-ISSN: 2226-3624 @ 2020 HRMARS

\begin{tabular}{|l|c|c|c|}
\hline $1990-2019$ & -23.34 & -2.76 & -616.5 \\
\hline $\begin{array}{l}2019- \\
2019 * *\end{array}$ & 0.92 & 0.113 & 0.134 \\
\hline $1990-2000$ & 0.23 & 1.438 & 0.362 \\
\hline $\begin{array}{l}2001- \\
2019 * *\end{array}$ & 0.132 & 0.544 & 0.135 \\
\hline \multicolumn{3}{|c|}{ Source: World Development Indicators, World Bank } \\
\hline $\begin{array}{l}\text { Notes: } \\
(*) \text { ICORs=(I/Y)/( } \Delta Y / Y) \\
(* *) \text { It excludes 1982, } 1983 \text { and 1986, during which the rate of } \\
\text { growth of } \\
\text { output was negative. }\end{array}$
\end{tabular}

